\title{
ANALISIS PERKEMBANGAN BAHASA ANAK USIA DASAR (TERCAPAI) DI MI MA`ARIF SAMBEGO
}

\author{
Bella Oktadiana \\ Program Magister FITK PGMI UIN Sunan Kalijaga Yogyakarta \\ bellaoktadianaabd@gmail.com \\ Esti Hayati \\ Program Magister FITK PGMI UIN Sunan Kalijaga Yogyakarta \\ estihayati10@gmail.com \\ Ira Agus Sofiana \\ Program Magister FITK PGMI UIN Sunan Kalijaga Yogyakarta \\ iraagussofiana@gmail.com
}

\begin{abstract}
This research (article) discusses the Language Development of Basic Children (Reached) in Mi Ma'arif Sambego Yogyakarta. The purpose of this study was to determine the language development of students of elementary age in MI Maarif Sembego. This type of research is descriptive qualitative, the informants of this study were class III students named Shaafira. The data collection tool in this study is in the form of observation, interviews and documentation. While the data that has been collected is then analyzed by descriptive qualitative data analysis techniques, namely data reduction, data presentation and conclusion (verification). The results of his research are the development of the language of children of elementary age (reached) in Mi Ma'arif Sambego Yogyakarta including: First phonetics, namely the sound of language. Both Morphology are changes in word form, as well as changes in the form of words to the meaning and class of words. Third Syntax is to sort words in menentuka meanings composed of Subjects, Predicates, Objects and Description. The fourth Semantic is knowing the meanings or meanings contained in each word in other words. And the Fifth Pragmatics is to use polite language in the right situations. And the results of the five aspects of language development in basic age children that almost all indicators are very well achieved. Only indicators of pragmatic development are still sufficient or are beginning to develop. As for the overall results of the development of the language knowledge of children of basic age in $M I M a^{\prime}$ arif Sambego, it can be said to be very good or already achieved.
\end{abstract}

Keywords: Development, Language, Achieved

Nazhruna: Jurnal Pendidikan Islam

Vol. 2 No 2 2019. Issn: 2614-8013. Hal.225-245

DOI: https://oi.org/10.31538/ nzh.v2i2.335 


\begin{abstract}
Abstrak
Penelitian (artikel) ini membahas tentang Perkembangan Bahasa Anak Usia Dasar (Tercapai) Di Mi Ma'arif Sambego Yogyakarta. Adapun tujuan dari penelitian ini adalah untuk mengetahui perkembangan bahasa anak siswa usia dasar di MI Maarif Sembego. Jenis penelitian ini adalah deskriptif kualitatif, informan penelitian ini adalah siswa kelas III yang bernama Shaafira. Adapun alat pengumpulan data dalam penelitian ini berupa observasi, wawancara dan dokumentasi. Sedangkan data yang telah dikumpulkan kemudian dianalisis dengan teknik analisis data deskriptif kualitatif yaitu reduksi data, penyajian data dan penarikan kesimpulan (verifikasi). Hasil penelitiannya adalah Perkembangan Bahasa Anak Usia Dasar (Tercapai) Di Mi Ma'arif Sambego Yogyakarta diantaranya: Pertama Fonetik yaitu bunyi bahasa . Kedua Morfologi yaitu Perubahan bentuk kata, serta perubahan bentuk kata terhadap arti dan golongan kata. Ketiga Sintaksis yaitu Mengurutkan kata dalam menentuka arti yang tersusun dari Subjek, Predikat, Objek dan Keterangan. Keempat Semantik yaitu Mengetahui arti-arti atau makna yang terkandung tiap kata dengan kata lain. Dan Kelima Pragmatik yaitu Menggunakan bahasa yang sopan dalam situasi-situasi yang tepat. Dan hasil capaian dari kelima aspek perkembangan bahasa anak usia dasar tersebut bahwa hampir keseluruhan indikator dicapai dengan sangat baik. Hanya indikator perkembangan pragmatik yang masih cukup atau mulai berkembang. Adapun untuk hasil keseluruhan perkembangan pengetahuan bahasa anak usia dasar di MI Ma'arif Sambego dapat dikatakan sangat baik atau sudah tercapai.
\end{abstract}

\title{
Kata kunci : Perkembangan, Bahasa, Tercapai
}

\section{PENDAHULUAN}

Setiap insan memiliki potensi yang sama untuk menguasai bahasa. Bahasa adalah suatu bentuk komunikasi entah itu lisan, tertulis atau isyarat yang berdasarkan pada suatu sistem dari simbol-simbol. Bahasa terdiri dari kata-kata yang digunakan oleh masyarakat beserta aturan-aturan untuk menyusun berbagai variasi dan mengombinasikannya. ${ }^{1}$ Menurut Vygotsky dalam Ahmad menyatakan bahwa bahasa merupakan alat untuk

1John W Santrock, Perkembangan Anak, (Jakarta: Erlangga,2007), hlm.353. 
mengekspresikan ide dan bertanya dan bahasa juga menghasilkan konsep dan kategori kategori berpikir. ${ }^{2}$

Perkembangan bahasa mengikuti suatu urutan yang dapat diramalkan secara umum sekalipun terdapat variasi diantara anak yang satu dengan anak yang lainnya, dengan tujuan untuk mengembangkan kemampuan anak berkomunikasi. ${ }^{3}$ Perkembangan bahasa selalu meningkat sesuai dengan meningkatnya usia anak. Perkembangan bahasa pada anak-anak sangat penting karena anak dapat mengembangkan kemampuan sosialnya (social skill) melalui berbahasa. Melalui bahasa, anak dapat mengekspresikan pikirannya menggunakan bahasa sehingga orang lain dapat menangkap apa yang dipikirkan oleh anak dan menciptakan suatu hubungan sosial. Pada saatnya anak akan dapat berkembang dan tumbuh menjadi pribadi yang bahagia karena dengan mulai berkomunikasi dengan lingkungan, bersedia memberi dan menerima segala sesuatu yang terjadi di lingkungannya.

Pengembangan bahasa memungkinkan anak belajar memahami dan mengontrol diri sendiri. Ketika anak belajar berbicara, secara tidak disengaja mereka mengembangkan pengetahuan tentang sistem fonologi, sintaksis, semantik dan sistem pragmatik. Pengetahuan tersebut, Ellis menyebutnya sebagai elemen bahasa. Pengetahuan ini, dapat dikembangkan oleh anak dalam kehidupan dilingkungannya, baik di rumah, dalam kehidupan bermain, dan si sekolah. Dalam kehidupan di sekolah, pengetahuan guru tentang bahasa anak berguna untuk kepentingan perencanaan, pelaksanaan, dan dalam evaluasi pembelajaran. Dengan demikian guru hendaklah memiliki pengetahuan yang luas tentang perkembangan bahasa anak dan cara mengembangkannya, agar kelak mereka memiliki keterampilan berbahasa yang benar dan baik, baik dalam mendengarkan, berbicara, membaca, maupun menulis. ${ }^{4}$

${ }^{2}$ Ahmad Susanto, Perkembangan Anak Usia Dini: Pengantar Dalam Berbagai Aspeknya, (Jakarta: Kencana,2012), hlm.73.

${ }^{3}$ Mansur, Pendidikan Anak Usia Dini dalam Islam, (Yogyakarta : Pustaka Pelajar ,2014), hlm.35.

${ }^{4}$ Ellis Gail dan Brewstar jean, The Storutelling Handbook for Primary Thachers England Penguin English,1989,hlm.79. 
Berdasarkan uraian dari latar belakang di atas, terdapat rumusan masalah yaitu: Mengetahui bagaimana perkembangan bahasa anak usia dasar yang tercapai di kelas III MI Ma'arif Sambego. Adapun tujuan dari penelitian ini adalah untuk mengetahui perkembangan bahasa anak siswa usia dasar di MI Maarif Sembego. Hasil penelitian ini diharapkan bermanfaat bagi kita semua agar memiliki pengetahuan yang luas tentang perkembangan bahasa anak, agar kelak mereka memiliki keterampilan berbahasa yang benar dan baik, baik dalam mendengarkan, berbicara, membaca, maupun menulis.

\section{METODE PENELITIAN}

Metodologi dalam penelitian ini menggunakan pendekatan deskriptif kualitatif. Artinya penelitian yang dilakukan dengan menjelaskan, menggambarkan, dan menguraikan pokok permasalahan yang hendak dibahas dalam penelitian ini yang berkaitan dengan perkembangan bahasa anak usia dasar di MI Ma'arif Bego, kemudiana ditarik kesimpulan secara deduktif. Jadi dalam pendekatan kualitatif tidak memakai angka tetapi berupa penjabaran di dalam kalimat. ${ }^{5}$

Teknik Pengumpulan Data, adapun teknik pengumpulan data yang diguanakan dalam penelitian ini yaitu: observasi, wawancara, dan dokumentasi. Subjek Penelitian ini yaitu siswa kelas III di MI Ma'arif Bego Kecamatan Depok Kabupaten Seleman Yogyakarta, yang berjumlah 1 siswa. Teknik analisis data yang digunakan dalam penelitian ini yaitu teknik analisis deskriptif kualitatif yang dapat dilakukan dengan tiga tahapan, seperti yang dikemukakan oleh Miles dan Huberman dalam Sugiyono yaitu Reduksi Data, Penyajian Data, Verifikasi. ${ }^{6}$ Dari ketiga tahapan tersebut, baru dapat diketahui bahwa perkembangan bahasa anak usia dasar di MI Ma'arif Bego.

Waktu penelitian dilaksanakan pada semester ganjil tahun pelajaran 2018/2019. Penelitian dilaksanakan dalam kurun waktu 2 minggu yaitu pada tanggal 17 Oktober 2018 sampai dengan 24 Oktober 2018, minggu pertama mengantaran surat kesekolah pada tanggal pada tanggal 17 Oktober 2018,

5Suharshimi Arikunto, Prosedur Penelitian: Suatu Pendekatan Praktik, (Jakarta: Rineka Cipta,2007), hlm.383. hlm.338.

'Sugiyono, Metode Penelitian Kuantitatif Kualitatif dan R\&D (Bandung: Alfabeta,2014), 
minggu kedua melakukan observasi serta wawancara kepada siswa berkaitan dengan perkembangan bahasa anak usia dasar serta pengambilan foto sebagai bukti dokumentasi bahwa telah melakukan observasi dan wawancara di MI Ma’arif Bego pada tanggal 24 Oktober 2018.

\section{HASIL PENELITIAN DAN ANALISIS}

Pada pembahasan ini akan menguraikan data hasil penelitian tentang perkembangan bahasa anak usia dasar kelas III di MI Ma'arif Bego, data ini bersumber dari siswa melalui teknik observasi dan wawancara, observasi dan wawancara ini dilakukan untuk mendapatkan data tentang perkembangan bahasa anak usia dasar kelas III .

Observasi dan wawancara dilakukan di kelas III selama 1 hari yang dilaksanakan pada tanggal 24 Oktober 2018. Observasi dan wawancara dilakukan kepada 1 orang siswa kelas III yang bernama Shaafira Yasmin Maitsaa yang biasa dipanggil Shaafira.

Indikator Pencapaian Perkembangan Bahasa Anak Usia Dasar

\begin{tabular}{|c|c|c|c|c|c|}
\hline \multirow[t]{2}{*}{ Karakteristik } & \multirow[t]{2}{*}{ Indikator } & \multicolumn{4}{|c|}{$\begin{array}{c}\text { Hasil } \\
\text { pengamatan }\end{array}$} \\
\hline & & TB & CB & B & SB \\
\hline Fonetik & $\begin{array}{l}\text { Mengikuti fonem } / \mathrm{l} / \text { atau } / \mathrm{r} / \\
\text { dalam konsonan rangkap } \\
\text { (contoh: lambat dan rambat) }\end{array}$ & & & & $\mathrm{v}$ \\
\hline Morfemik & $\begin{array}{l}\text { Perubahan bentuk kata, serta } \\
\text { perubahan bentuk kata terhadap } \\
\text { arti dan golongan kata } \\
\text { (contoh: kata baca menjadi } \\
\text { dibaca, membaca, dibacakan, } \\
\text { membacakan, pembacaan) }\end{array}$ & & & & $\mathrm{V}$ \\
\hline Sintaksis & $\begin{array}{l}\text { Mengurutkan kata dalam } \\
\text { menentuka arti yang tersusun } \\
\text { dari Subjek, Predikat, Objek dan } \\
\text { Keterangan. } \\
\text { (contoh: kalimat "sebastian } \\
\text { mendorong sepeda" memiliki } \\
\text { arti yang berbeda dengan } \\
\text { "sepeda mendorong sebastian") }\end{array}$ & & & & V \\
\hline
\end{tabular}




\begin{tabular}{|l|l|l|l|l|l|}
\hline Semantik & $\begin{array}{l}\text { Mengetahui arti-arti tiap kata } \\
\text { dengan kata lain (contoh : kata } \\
\text { "anak perempuan dan wanita", } \\
\text { "Banting tulang dan kerja keras" } \\
\text { memiliki kesamaan ciri semantik } \\
\text { tetapi berbeda secara semantik) }\end{array}$ & & & & \\
\hline Pragmatik & $\begin{array}{l}\text { Menggunakan bahasa yang } \\
\text { sopan dalam situasi-situasi yang } \\
\text { tepat (contoh: Ibu, Saya izin ke } \\
\text { belakang mau buang air kecil) }\end{array}$ & $\vee$ & & \\
\hline
\end{tabular}

Tabel 1. Indikator pencapaian perkembangan bahasa anak usia dasar

Berdasarkan tabel 1 diatas maka perkembangan bahasa anak usia dasar dapat diketahui bahwa bahasa anak terus berkembang di kelima aspek perkembangan bahasa yaitu: fonetik, morfologi, simantik, sintaksis,dan pragmatik. Berikut ini diuraikan bagaimana aspek perkembangan bahasa anak usia dasar tersebut:

a. Fonetik

Fonetik sebagai salah satu aspek dalam linguistik mempelajari fonem. Secara umum fonem dapat didefinisikan dua bunyi yang secara fonetis berbeda dalam lingkungan yang sama, yang berpengaruh untuk membedakan kata-kata yang berlainan. Misalnya (l) dan (r) adalah fonemfonem yang berbeda dalam bahasa Indonesia karena membedakan arti misalnya ialah pasangan kata-kata lambat dan rambat, laga dan raga, dan sebagainya. ketika peneliti memerintahkan Shaafira untuk menyebutkan fonem / / atau / r/ dalam konsonan rangkap seperti yang dicontohkan tadi maka Shaafira mampu mengucapkannya secara baik dan benar, dari sini dapat diketahui bahwa Shaafira dapat menyebutkan fonem /1/ atau /r/ dalam konsonan rangkap dengan sangat baik.

b. Morfologi

Morfologi secara umum dapat didefinisikan sebagai ilmu bahasa yang mempelajari seluk beluk bentuk kata, perubahan bentuk kata, serta perubahan bentuk kata terhadap arti dan golongan kata ${ }^{7}$ Ketika peneliti

${ }^{7}$ Hasyim Asy'ari, "Keistimewaan Bahasa Arab Sebagai Bahasa Al-Qur'an," Nidhomul Haq : Jurnal Manajemen Pendidikan Islam 1, no. 1 (2016): 21-28, https://doi.org/10.31538/ndh.v1i1.5. 
meminta Shaafira untuk mengucapkan berbagai bentuk kata seperti: Dari kata baca, maka Shaafira mampu mengucapkan berbagai bentuk kata dari kata baca tersebut yaitu menjadi dibaca, membaca, dibacakan, membacakan, pembacaan. dari sini diketahui bahwa Shaafira dapat mengucapkan berbagai bentuk kata dalam bidang morfologi dengan sangat baik.

c. Sintaksis

Sintaksis yaitu ilmu bahasa yang mempelajari prinsip dan peraturan dalam membuat kalimat. Sintaksis tersusun dari Subjek, Predikat, Objek dan Keterangan. Ketika peneliti meminta Shaafira untuk menunjukkan sintaksis dari kalimat "sebastian mendorong sepeda" maka Shaafira mampu menujukkan Subjek, Predikat, dan Objek dari dari kalimat "sebastian( $\mathrm{S}$ ) mendorong $(\mathrm{P})$ sepeda $(\mathrm{O})$ " dari sini diketahui bahwa Shaafira dapat menyusun kalimat berdasarkan dari Subjek, Predikat, dan Objek dalam bidang Sintaksis dengan sangat baik.

d. Semantik

Semantik yaitu ilmu bahasa yang mempelajari makna yang terkandung dalam suatu bahasa. Ketika peneliti meminta Shaafira untuk mencari makna yang terkandung dalam suatu bahasa. Seperti kata anak perempuan maka Shaafira menjawab maknanya adalah wanita, kemudian peneliti meminta Shaafira untuk mencari makna yang terkandung dalam suatu bahasa lagi seperti kata Banting tulang maka Shaafira menjawab maknanya adalah kerja keras. dari sini diketahui bahwa Shaafira dapat mengetahui makna yang terkandung dalam suatu bahasa dalam bidang Simantikk dengan sangat baik.

e. Pragmatik

Pragmatik yaitu ilmu bahasa yang mempelajari hubungan antara konteks dan makna. Pragmatik mengkaji kondisi-kondisi penggunaan bahasa manusia yang ditentukan oleh konteks kemasyarakatan. Pragmatik disini lebih seperti menggunakan bahasa yang sopan dalam situasi-situasi yang tepat. Ketika peneliti meminta Shaafira untuk mencontohkan bagaimana menggunakan bahasa yang sopan untuk meminta izin membuang air kecil maka Shaafira mencontohkannya seperti berikut "Ibu saya izin ke wc/toilet mau pipis". Secara pragmatik izin ke wc/toilet sepertinya kurang sopan didengar jadi sebaiknya kata wc/toilet itu diganti bahasa lain seperti "Ibu saya Saya izin ke belakang mau buang air kecil", 
jadi secara pragmatik izin ke belakang bermakna saya izin ke toilet. Dari sini dapat diketahui bahwa Shaafira menggunakan bahasa yang sopan dalam situasi-situasi yang tepat dengan cukup baik.

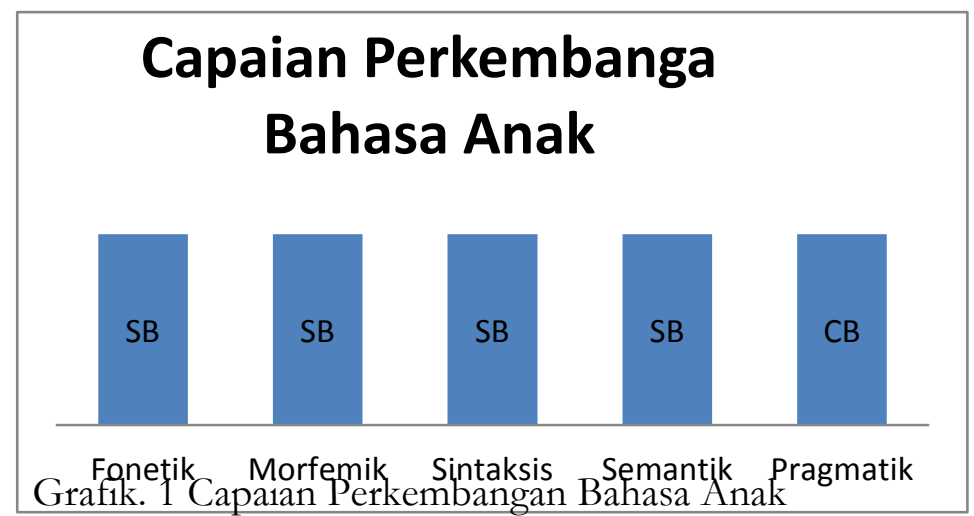

Jika dilihat dari grafik di atas, dapat disimpulkan bahwa hampir keseluruhan indikator dicapai dengan sangat baik. Hanya indikator perkembangan pragmatik yang masih cukup atau mulai berkembang. Adapun untuk hasil keseluruhan perkembangan pengetahuan bahasa anak usia dasar di MI Ma'arif Sambego dapat dikatakan sangat baik atau sudah tercapai.

\section{PEMBAHASAN}

\section{Perkembangan Bahasa Anak Usia Dasar}

Bahasa merupakan kemampuan untuk berkomunikasi dengan orang lain. Dalam pengertian ini, tercakup semua cara untuk berkomunikasi, dimana pikiran dan perasaan dinyatakan dalam bentuk lambang atau simbol untuk mengungkapkan sesuatu pengertian, seperti dengan menggunakan lisan, tulisan, isyarat, bilangan, lukisan, dan mimik muka.

Penelitian yang dilakukan terhadap perkembangan bahasa anak tentunya tidak terlepas dari pandangan, hipotesis, atau teori psikologi yang dianut. Dalam hal ini sejarah telah mencatat adanya tiga pandangan atau teori dalam perkembangan bahasa anak. Teori tersebuat adalah sebagai berikut: 1) Teori Nativis, Pandangan ini diwakili oleh Noam Chomsky. Pandangan ini berpendapat bahwa selama perkembangan awal system linguistik berfungsi secara independen dan tidak dipengaruhi oleh system kognitif dan lingkungan 
sosial. ${ }^{8}$ Para pengikut pandangan nativist berpendapat bahwa lingkungan tidak berpengaruh dalam pemerolehan bahasa, melainkan menganggap bahwa bahasa merupakan bawaan biologis yang menjadikan anak mampu memperoleh dengan sendirinya.

Para ahli nativis menjelaskan bahwa kemampuan berbahasa dipengaruhi oleh kematangan seiring dengan pertumbuhan anak. Pandangan para ahli nativis yang memisahkan antara belajar bahasa dengan perkembangan kognitif dikritik berkenaan dengan kenyataan bahwa anak belajar bahasa dari ligkungan sekitarnya dan memiliki kemampuan untuk mengubah bahasanya jika lingkungannya berubah. 2) Teori Behavioristik, Pandangan ini diwakili oleh B.F Skinner, yang menekankan bahwa proses pemerolahan bahasa pertama dikendalikan dari luar diri si anak, yaitu oleh rangsangan yang diberikan melalui lingkungan.

Menurut kaum behavioris kemampuan berbicara dan memahami bahasa oleh anak diperoleh melalui rangsangan dari lingkungannya. Dan kemampuan yang sebenarnya dalam berkomunikasi adalah dengan prinsip pertalian S-R (stimuls-respons) dan proses peniruan-peniruan. 3) Jean Piaget menyatakan bahwa bahasa itu bukanlah suatu ciri alamiah yang terpisah, melainkah salah satu di antara beberapa kemampuan yang berasal dari kematangan kognitif. Bahasa distrukturi oleh nalar, maka perkembangan bahasa harus berlandas pada perubahan yang lebih mendasar dan lebih umum di dalam kognisi. Jadi, urut-urutan perkembangan kognitif menentukan urutan perkembangan bahasa.

M. Schaerlaekens membagi fase-fase perkembangan bahasa anak dalam empat periode. Perbedaan ini didasarkan pada ciri-ciri tertentu yang khas pada setiap periode. Adapun periode-periode tersebut adalah sebagai berikut: ${ }^{10}$

${ }^{8}$ Kuhl., P.K \& Meltzoff, A. N, Evolution, Nativism and Learning in the Development of Language and Speech, (New York: Oxford University Press,1997), hlm.8.

${ }^{9}$ Ibid, hlm.8.

${ }^{10}$ Samsunuwiyati Mar'at, Psikolinguistik: Suatu Pengantar, (Bandung: PT Refika Aditama), hlm.61. 


\begin{tabular}{|c|c|}
\hline Periode & Perkembangan \\
\hline $\begin{array}{l}\text { Periode Prelingual } \\
\text { (usia 0-1 tahun) }\end{array}$ & $\begin{array}{l}\text { Disebut dengan periode prelingual karena anak } \\
\text { belum dapat mengucapkan 'bahasa ucapan' seperti } \\
\text { yang diucapkan orang dewasa, dalam arti belum } \\
\text { mengikuti aturan-aturan bahasa yang berlaku. } \\
\text { Namun perkembangan 'menghasilkan' bunyi-bunyi } \\
\text { itu sudah mulai pada minggu-minggu sejak } \\
\text { kelahirannya. Perkembangan tersebut menurut } \\
\text { Chaer melalui tahap-tahap sebagai berikut: (1). Bunyi } \\
\text { resonansi, (2). Bunyi berdekut, (3). Bunyi berleter, } \\
\text { (4). Bunyi berleter ulang, (5). Bunyi vokabel. (Chaer, } \\
\text { 2003:230-233) }\end{array}$ \\
\hline $\begin{array}{l}\text { Periode Lingual Dini } \\
\text { (usia 1-2,5 tahun) }\end{array}$ & $\begin{array}{l}\text { Pada periode ini anak mulai mengucapkan } \\
\text { perkataannya yang pertama, meskipun belum } \\
\text { lengkap. Misalnya: atit (sakit), agi (lagi), dan } \\
\text { seterusnya. Pada masa ini beberapa kombinasi huruf } \\
\text { masih terlalu sukar diucapkan, juga beberapa huruf } \\
\text { masih sukar diucapkan, seperti: r, s, k, j, dan t. } \\
\text { Pertambahan kemahiran berbahasa pada periode ini } \\
\text { sangat cepat dan dapat dibagi dalam tiga periode, } \\
\text { yaitu: (a). Periode kalimat satu kata (holophrare), (b). } \\
\text { Periode kalimat dua kata, (c). Periode kalimat lebih } \\
\text { dari dua kata (more word sentence). (Mar'at, 2005 : 62- } \\
\text { 66.) }\end{array}$ \\
\hline $\begin{array}{l}\text { Periode Diferensiasi } \\
\text { (usia 2,5- } 5 \text { tahun) }\end{array}$ & $\begin{array}{l}\text { Yang menyolok pada periode ini ialah ketrampilan } \\
\text { anak dalam mengadakan diferensiasi dalam } \\
\text { penggunaan kata-kata dan kalimat kalimat. }\end{array}$ \\
\hline $\begin{array}{l}\text { Periode Menjelang } \\
\text { Sekolah (sesudah usia } \\
5 \text { tahun) }\end{array}$ & $\begin{array}{l}\text { Menurut Chaer, yang dimaksud dengan menjelang } \\
\text { sekolah di sini adalah menjelang anak masuk sekolah } \\
\text { dasar; yaitu pada waktu mereka berusia antara lima } \\
\text { sampai enam tahun. Pendidikan di TK, apalagi } \\
\text { kelompok bermain (play group) belum dapat dianggap }\end{array}$ \\
\hline
\end{tabular}




\begin{tabular}{|l|l|}
\hline & $\begin{array}{l}\text { sebagai sekolah, sebab sifatnya hanya menolong anak } \\
\text { untuk siap memasuki pendidikan dasar. (Chaer, } \\
2003: 237)\end{array}$ \\
\hline
\end{tabular}

Tabel 2. periode perkembangan bahasa anak usia dasar

Perkembangan bahasa anak usia dasar yang tercapai pada subjek ini dilakukan pada kelas 1-3 sekolah dasar atau sekitar umur 6-8, sebab subjek yang diteliti berumur 8 tahun. Tingkat perkembangannya dapat diketahui dari hasil observasi. Berikut tahapan-tahapan perkembangan anak usia dasar. ${ }^{11}$

\begin{tabular}{|l|l|l|}
\hline \multicolumn{1}{|c|}{ Karakteristik } & \multicolumn{1}{|c|}{ Deskripsi } & \multicolumn{1}{|c|}{ Indikator } \\
\hline Fonetik & $\begin{array}{l}\text { Sistem suara dalam } \\
\text { sebuah bahasa. Sebuah } \\
\text { fonem adalah unit } \\
\text { terkecil dalam sebuah } \\
\text { bahasa. }\end{array}$ & $\begin{array}{l}\text { Mengikuti fonem /l/ atau /r/ } \\
\text { dalam konsonan rangkap }\end{array}$ \\
\hline Morfemik & $\begin{array}{l}\text { Sistem dari unit-unit } \\
\text { bermakna yang terlibat } \\
\text { dalam pembentukan } \\
\text { kata. }\end{array}$ & $\begin{array}{l}\text { Perubahan bentuk kata, serta } \\
\text { perubahan bentuk kata } \\
\text { terhadap arti dan golongan } \\
\text { kata }\end{array}$ \\
\hline Sintaksis & $\begin{array}{l}\text { Sistem yang melibatkan } \\
\text { bagaimana kata di } \\
\text { kombinasikan sehingga } \\
\text { membentuk frasa-frasa } \\
\text { dan kalimat-kalimat yang } \\
\text { dapat diterima. }\end{array}$ & $\begin{array}{l}\text { Mengurutkan kata dalam } \\
\text { menentuka arti yang tersusun } \\
\text { dari Subjek, Predikat, Objek } \\
\text { dan Keterangan. }\end{array}$ \\
\hline Semantik & $\begin{array}{l}\text { Sistem yang melibatkan } \\
\text { arti kata-kata dan } \\
\text { kalimat. }\end{array}$ & $\begin{array}{l}\text { Mengetahui arti-arti tiap kata } \\
\text { dengan kata lain }\end{array}$ \\
\hline Pragmatik & $\begin{array}{l}\text { Sistem menggunakan } \\
\text { percakapan } \\
\text { pengetahuan yang tepat }\end{array}$ & $\begin{array}{l}\text { Menggunakan bahasa yang } \\
\text { sopan dalam situasi-situasi } \\
\text { yang tepat }\end{array}$ \\
\hline
\end{tabular}

${ }^{11}$ John W. Santrock, Perkembangan Anak ...,hlm.355. 
Vol. 2 No 22019

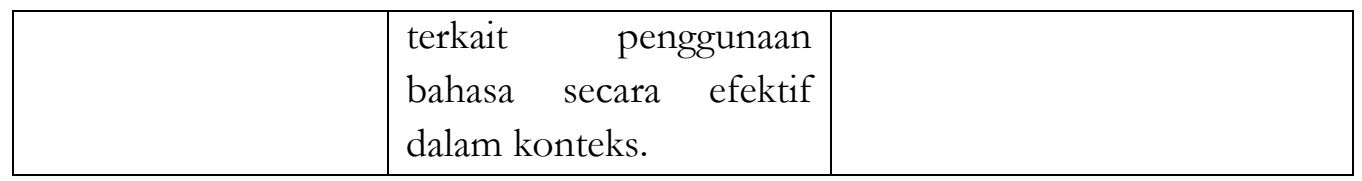

Tabel 3. Indikator pencapaian perkembangan bahasa anak usia dasar

Berdasarkan tabel diatas selama masa sekolah dasar (kelas 1-3), bahasa anak terus berkembang di kelima aspek pengetahuan bahasa: fonetik, morfemik, simantik, sintaksis,dan pragmatik. Selama Observasi dapat terlihat dengen jelas perkembangan bahasa pada subjek Shafiraa tercapai dengan baik. Dikatakan demikian karena berdasarkan analisis indikator yang harus dicapai pada perkembangan bahasa pada anak kelas 3, banyak yang terlihat. Adapun uraian indikator perkembangan bahasa anak usia dengan perilaku dan sikap yang ditunjukkan saat proses observasi antara lain:

\section{Perkembangan pengetahuan fonetik}

Fonologi setiap bahasa dibentuk dari suara-suara dasar. Fonologi adalah sistem suara dari suatu bahasa, termasuk suara-suara yang digunakan da bagaimana suara-suara tersebut di kombinasikan. ${ }^{12}$

Pada bagian ini, perkembangan pengetahuan fonetik antara anak-anak sekolah dasar akan dipaparkan. Masa sekolah dasar merupakan waktu dimana anak mencapai penguasaan fonem-fonem, dan lagi, selama waktu ini, penegtahuan fonetik anak sangat di pengaruhi oleh pengalaman-pengalaman mereka dalam membaca dan menulis.

Jika dilihat dari hasil observasi dan wawancara yang dilakukan peneliti terhadap shafiraa tentang perkembangan pengetahuan fonetik shafiraa mampu mengucapkan huruf (l) dan (r) adalah fonem-fonem yang berbeda dalam bahasa Indonesia karena membedakan arti misalnya ialah pasangan kata-kata lambat dan rambat, laga dan raga, dan sebagainya. ketika peneliti memerintahkan Shaafira untuk menyebutkan fonem /1/ atau /r/ dalam konsonan rangkap seperti yang dicontohkan tadi maka Shaafira mampu mengucapkannya secara baik dan benar, dari sini dapat diketahui bahwa Shaafira dapat menyebutkan fonem /1/ atau /r/ dalam konsonan rangkap dengan sangat baik.

12 Ibid, hlm.353. 
Sebagaimana dengan sebuah penelitian yang dilakukan Prima Gusti Yanti dengan judul "Pemerolehan Bahasa Anak: Kajian Aspek Fonologi Pada Anak" penelitian ini menggambarkan bahwa Secara umum pemerolehan fonologi TPM mengikuti urutan yang sifatnya universal sesuaidengan teori pemerolehan bahasa. ${ }^{13}$ Konsep universal Jakobson dalam Dardjowijojo ditemukan dalam pemerolehan fonologi TPM, baik dalam pemerolehan vokal maupun konsonan. Dalam hal bunyi vokal terdapat tiga vokal utama yang muncul terlebih dahulu, yaitu [i], [u], dan [a]. Sistem kontras seperti ini disebut sistem vokal minimal dan terdapat dalam semua bahasa. ${ }^{14}$

Penelitian juga di lakuan oleh Ida Hamidah dengan judul " Pemerolehan Bahasa Pada Anak Usia 3,5 Tabun Berdasarkan Aspek. Fonolog " berdasarkan penelitian terhadap PM yang sudah menguasai bunyi konsonan $[\mathrm{b}],[\mathrm{c}],[\mathrm{d}],[\mathrm{f}],[\mathrm{g}],[\mathrm{h}]$, [j], [k], [1], [m], [n], [p], [r], [s], [t], [w], dan [y] pada umur 3 tahun 4 bulan. Sedangkan pemerolehan vokal PM sudah dikuasai semenjak ia mulai menuturkan kata-kata sesuai teori Jacobson. ${ }^{15}$

Dikatakan oleh Owens dan Sander dalam buku Perkembangan anak Beverly Otto Pada usia ke 6 atau ke 7 tahun, anak-anak terus meningkatkan kemampuannya dalam menghasilkan bunyi-bunyi spesifik dalam bahasa secara lengkap. Pada usia 8 tahun, sebagian anak telah melengkapi produksi fonetiknya. Pemerolehan gugusan konsonan mungkin belum terjadi sampai anak berusia 8 tahun. Sementara beberapa anak sudah memperoleh artikulasi tersebut terlebih dahulu. ${ }^{16}$ Senada dengan deskripsi diatas bahwa berdasarkan penggalian data dari hasil observasi kami dengan siswa kelas III MI Ma'arif Sambego yang bernama shafiraa bahwa dia sudah bisa mengikuti fonem /1/ atau /r/ dalam konsonan rangkap.

13 Prima Gusti Yanti, Pemerolehan Bahasa Anak: Kajian Aspek Fonologi Pada Anak, (dalam Jurnal Ilmiah VISI PPTK PAUDNI - Vol. 11, No. 2, Desember 2016).

${ }^{14}$ Dardjowidjojo S, Psikolinguistik; Pengantar Pemahaman Bahasa Manusia. (Jakarta. Yayasan Obor Indonesia, 2005), hlm.238.

${ }^{15}$ Ida, Hamidah, "Pemerolehan Bahasa Pada Anak Usia 3,5 Tabun Berdasarkan Aspek Fonolog", (dalam Jurnal Ilmiah SPS Pendidikan Bahasa Indonesia, Vol 1, No. 1, Agustus, 2018. hlm.348.

${ }^{16}$ Beverly Otto, Perkembangan Bahasa Pada Anak Usia Dini, (Jakarta: Kencana, 2015), 


\section{Perkembangan Pengetahuan Morfemik}

Morfologi merupakan ilmu yang membicarakan morfem serta bagaimana morfem itu dibentuk menjadi kata. Morfem adalah unsur terkecil dari pembentukan kata dan disesuaikan dengan aturan suatu bahasa. Pada bahasa Indonesia morfem dapat berbentuk imbuhan. Misalnya kata prasangka memiliki dua morfem yaitu /pra/ dan /sangka/. Kata sangka merupakan kata dasar, penambahan pra menyebabkan perubahan arti pada kata sangka.

Menurut J.W Santrock morfologi mengacu pada unit-unit makna yang membentuk formasi kata. Sebuah morfem adalah unit terkecil yang masih memiliki makna, yang berupa kata (atau bagian kata) yang tidak dapat di pecah lagi menjadi bagian bermakna yang lebih kecil. ${ }^{17}$ Jika dilihat dari hasil observasi dan wawancara yang dilakukan peneliti terhadap shafiraa tentang perkembangan pengetahuan morfemik,Shaafira mampu mengucapkan berbagai bentuk kata seperti: Dari kata baca, maka Shaafira mampu mengucapkan berbagai bentuk kata dari kata baca tersebut yaitu menjadi dibaca, membaca, dibacakan, membacakan, pembacaan. dari sini diketahui bahwa Shaafira dapat mengucapkan berbagai bentuk kata dalam bidang morfologi dengan sangat baik.

Sebagaimana dengan sebuah penelitian yang dilakukan oleh Lenny Nuraeni dengan judul "Pemerolehan Morfologi (Verba) Pada Anak Usia 3, 4 Dan 5 Tabun (Suatu Kajian Neuro Psikolinguistike)" hasil penelitian bahwa konsep universal yang dipatuhi oleh anak dalam pemerolehan bahasa ini tidak merata, tampak sangat nyata bahwa dalam pemerolehan Verba, faktor masukan dari lingkungan sangat berpengaruh pada anak. Alifia Septima Zahra yang berusia 3 Tahun terlihat telah banyak memiliki perbendaharaan kata benda atau Verba dasar yang merupakan verba yang berupa morfem dasar bebas. Sedangkan untuk Verba turunan, afiksasi sudah mulai dilakukan meskipun baru - kell dan —nyall. Pada kata pengulangan yang terlihat, Alifia masih banyak melakukan pengulangan yang bukan memiliki makna

${ }^{17}$ John W. Santrock, Perkembangan Anak ..., hlm.355. 
pengulangan. Pengulangan yang dilakukan sepertinya berupa penegasan agar mitra bicaranya mengerti apa yang dimaksudkannya. ${ }^{18}$

Sejalan dengan Otto dalam buku perkembangan bahasa usia dini mengatakan selama masa sekolah dasar, anak-anak menjadi lebih memahami secara sadar mengenai morfemik yang ditambahkan pada kata untuk mengubah maksud atau mengubah fungsi sintaksis dalam kata. ${ }^{19}$ Senada dengan deskripsi diatas bahwa berdasarkan penggalian data dari hasil observasi kami dengan siswa kelas III MI Ma'arif Sambego yang bernama shafiraa bahwa dapat dikatakan, idealnya tahapan perkembangan morfemik ini sudah dicapai oleh shafiraa bahkan sudah membiasakannya dalam kehidupan sehari-hari.

\section{Perkembangan Pengetahuan Semantik}

Semantik adalah ilmu yang mempelajari arti dan makna dari suatu bahasa yang dibentuk dalam suatu kalimat. Selama masa sekolah dasar dan berlanjut pada tingkat diatasnya, perkembangan konseptual dan kosakata anak meningkat secara signifikan dan menjadi dasar yang penting untuk pemahaman membaca ${ }^{20}$.

Menurut Santrock semantik mengacu pada makna kata dan kalimat. setiap kata memiliki sekumpulan makna semantik atau atribut-atribut penting terkait makna kata. ${ }^{21}$ Jika dilihat dari hasil observasi dan wawancara yang dilakukan peneliti terhadap shafiraa tentang perkembangan pengetahuan semantik, Shaafira mampu untuk mencari makna yang terkandung dalam suatu bahasa. Seperti kata anak perempuan maka Shaafira menjawab maknanya adalah wanita, kata Banting tulang maka Shaafira menjawab maknanya adalah kerja keras. dari sini diketahui bahwa Shaafira dapat mengetahui makna yang terkandung dalam suatu bahasa dalam bidang Simantik dengan sangat baik.

${ }^{18}$ Lenny Nuraeni, Pemeroleban Morfologi (Verba) Pada Anak Usia 3, 4 Dan 5 Tabun (Suatu Kajian Neuro Psikolinguistik),", (dalam Jurnal Tunas Siliwangi Vol.1 | No.1 | Oktober, 2015).“

${ }^{19}$ Beverly Otto, Perkembangan Bahasa..., hlm.350.

${ }^{20}$ Inchinia Angger Rowin, "Verbalisme Bahasa Arab Dalam Kehidupan Beragama Masyarakat Muslim," Nazhruna: Jurnal Pendidikan Islam 1, no. 1 (16 Agustus 2018): 20-36, https://doi.org/10.31538/nzh.v1i1.40.

${ }^{21}$ John W. Santrock, Perkembangan Anak ..., hlm.355. 
Sebagaimana dengan sebuah penelitian yang dilakukan oleh Nurjamiaty dengan judul "Pemerolehan Bahasa Anak Usia Tiga Tahun Berdasarkan Tontonan Kesukaannya Ditinjau Dari Kontruksi Semantik." mengatakan bahwa Anak umur tiga tahun sudah mampu menyusun kalimat dalam bertutur meskipun masih sangat sederhana dan terbatas. Pada proses pemerolehan makna kata pada bahasa anak usia 3 tahun terdapat lima gejala transisi semantic kata, yaitu gejala (1) spesifikasi berlebihan, (2) generalisasi berlebihan, (3) tumpang tindih, (4) menuju spesifikasi makna, dan (5) penggunaan asosiasi makna. ${ }^{22}$

Sejalan dengan Otto dalam buku perkembangan bahasa usia dini mengatakan selama masa sekolah dasar dan berlanjut pada tingkat atasnya, perkembangan konseptual dan kosakata anak meningkat secara signifikan dan menjadi dasar yang penting untuk pemahaman membaca. ${ }^{23}$ Sehingga dapat dikatakan, idealnya tahapan perkembangan semantik ini sudah dicapai oleh shafiraa bahkan sudah membiasakannya dalam kehidupan sehari-hari.

\section{Perkembangan Pengetahuan Sintaksis}

Sintaksis adalah penggabungan kata menjadi kalimat berdasarkan aturan sistematis yang berlaku pada bahasa tertentu. Dalam bahasa Indonesia terdapat aturan Subjek, Predikat, dan Objek (SPO). Aturan ini berbeda pada bahasa lainnya. Menurut J.W Santrock sintaksis meliputi bagaimana kata-kata dikombinasikan sehingga membentuk frasa-frasa dan kalimat-kalimat yang dapat dimengerti. ${ }^{24}$

Jika dilihat dari hasil observasi dan wawancara yang dilakukan peneliti terhadap shafiraa tentang perkembangan pengetahuan sintaksis, Shaafira mampu untuk menunjukkan sintaksis dari kalimat "sebastian mendorong sepeda" maka Shaafira mampu menujukkan Subjek, Predikat, dan Objek dari dari kalimat "sebastian( S) mendorong (P) sepeda (O)" dari sini diketahui

${ }^{22 N u r j a m i a t y, ~ " P e m e r o l e h a n ~ B a h a s a ~ A n a k ~ U s i a ~ T i g a ~ T a b u n ~ B e r d a s a r k a n ~ T o n t o n a n ~}$ Kesukaannya Ditinjau Dari Kontruksi Semantik”, (dalam Jurnal Edukasi Kultura Vol.2 No.2 September, 2015).

${ }^{23}$ Beverly Otto, Perkembangan Bahasa..., hlm.350.

${ }^{24}$ John W. Santrock, Perkembangan Anak ..., hlm.353. 
bahwa Shaafira dapat menyusun kalimat berdasarkan dari Subjek, Predikat, dan Objek dalam bidang Sintaksis dengan sangat baik.

Sebagaimana penelitian yang dilakukan oleh Mushaitir dengan judul "Pemerolehan Sintaksis (B1) Bahasa Sasak Pada Anak Usia 4-6 Tabun", Berdasarkan hasil analisis dan pembahasan, dapat disimpulkan bahwa dalam pemerolehan sintaksi (B1) anak usia 4-6 tahun, seorang anak sudah mampu membentuk suatu pola kalimat, baik dalam bentuk kalimat tunggal dan kalimat majmuk. ${ }^{25}$

Penelitian juga dilakukan oleh Dyah Rohma Wati dengan judul "Sendi Sintaksis Dalam Pemerolehan Bahasa Pertama (Sebuab Studi Kasus)" Berdasarkan hasil pengamatan peneliti dalam sendi sintaksis, pemerolehan bahasa pada usia 20 bulan mencakup tahap dua kata, selanjutnya pada awal usia 21 bulan anak sudah mampu mengucapkan tiga kata. Bentuk-bentuk ujaran yang sudah dikuasai adalah ujaran deklaratif, imperatif, interogatif. Penggunaan bentuk-bentuk pronomina (ini, itu), deiksis tempat (disini disana), dan adjektiva(panjang, besar, enak, cantik), serta kata keterangan (juga, sudah) juga digunakan dalam ujaran. ${ }^{26}$

Sejalan dengan Otto dalam buku perkembangan bahasa usia dini mengatakan selama sekolah dasar, perkembangan bahasa anak dicirikan dengan meningkatnya kompleksitas sintaksis, pemahaman yang lebih jelas mengenai bagaimana kata ganti digunakan, dan pemahaman yang lebih besar serta penggunakan kalimat dengan struktur kalimat pasif. ${ }^{27}$ Sehingga dapat dikatakan, idealnya tahapan perkembangan sintaksis ini sudah dicapai oleh shafiraa bahkan sudah membiasakannya dalam kehidupan sehari-hari.

${ }_{25}$ Mushaitir. "Pemerolehan Sintaksis (B1) Bahasa Sasak Pada Anak Usia 4-6 Tabun", (dalam Jurnal Pendidikan Bahasa dan Sastra, Volume 16, Nomor 1, April 2016).

${ }^{26}$ Dyah, Rohma Wati. "Sendi Sintaksis Dalam Pemerolehan Babasa Pertama (Sebuab Studi Kasus)".

${ }^{27}$ Beverly Otto, Perkembangan Bahasa..., hlm.354. 


\section{Perkembangan Pengetahuan Pragmatik}

Pragmatik adalah aturan-aturan pemakaian bahasa, yaitu pemilihan bentuk bahasa dan penentuan maknanya sehubungan dengan maksud pembicara sesuai dengan konteks dan keadaannya. ${ }^{28}$ Pragmatic juga diartikan sebagai syarat-syarat yang mengakibatkan serasi-tidaknya pemakaian bahasa dalam komunikasi ; aspek-aspek pemakaian bahasa atau konteks luar bahasa yang memberikan sumbangan kepada makna ujaran. ${ }^{29}$ Menurut J.W Santrock pragmatik yakni penggunaan bahasa yang tepat dalam konteks yang berbeda. Pragmatik meliputi banyak wilayah. ${ }^{30}$

Jika dilihat dari hasil observasi dan wawancara yang dilakukan peneliti terhadap shafiraa tentang perkembangan pengetahuan pragmatik, Shaafira mampu untuk mencontohkan bagaimana menggunakan bahasa yang sopan untuk meminta izin membuang air kecil maka Shaafira mencontohkannya seperti berikut "Ibu saya izin ke wc/toilet mau pipis". Secara pragmatik izin ke wc/toilet sepertinya kurang sopan didengar jadi sebaiknya kata wc/toilet itu diganti bahasa lain seperti "Ibu saya Saya izin ke belakang mau buang air kecil", jadi secara pragmatik izin ke belakang bermakna saya izin ke toilet. Dari sini dapat diketahui bahwa Shaafira menggunakan bahasa yang sopan dalam situasi-situasi yang tepat dengan cukup baik.

Sebagaimana dengan sebuah penelitian yang dilakukan oleh Laode Abdul Wahab dengan judul "Pemerolehan Pragmatik Pada Anak Usia 3 Tahun (Studi Pada Asysyifa Ibra Him Warga Kendari Barat)” menunjukan bahwa pada setiap konteks dialog terdapat pelanggaran terhadap maksim-maksim dengan frekuensi tertentu. Sebagian jawaban nara sumber bersifat lugas dan sangat informatif atau sudah mematuhi maksim kuantitas, kualitas, relevansi, dan

${ }^{28}$ P.W.J Nababan, Ilmu Pragmatik (Teori dan Penerapannya), (Jakarta: Depdiknas, 1987), hlm 2.

${ }^{29}$ Harimurti Kridalaksana, Kamus Linguistik, Jakarta: Gramedia Pustaka Utama: 1993), hlm.177.

${ }^{30}$ John W. Santrock, Perkembangan Anak...,h lm.353. 
cara. Pelanggaran maksim lebih disebabkan tidak memadainya pengetahuan nara sumber. ${ }^{31}$

Menurut Beverly Otto dalam buku perkembangan bahasa usia dini mengatakan selama masa sekolah dasar, pengetahuan morfemik anak-anak terus berkembang begitu mereka terlibat dalam percakapan informal dengan orang lain dan juga dalam kegatan kelas. ${ }^{32}$ Senada dengan deskripsi di atas, kondisi yang terjadi pada shafiraa tidak demikian. Dalam menggunakan bahasa yang sopan dalam situasi-situasi yang tepat masih belum tercapai namun bisa dikatakan cukup baik.

\section{KESIMPULAN}

Berdasarkan uraian dan analisis di atas maka dapat disimpulkan sebagai berikut: Perkembangan Bahasa Anak Usia Dasar (Tercapai) Di MI Ma'arif Sambego Yogyakarta diantaranya: Pertama Fonetik yaitu bunyi bahasa . Kedua Morfologi yaitu Perubahan bentuk kata, serta perubahan bentuk kata terhadap arti dan golongan kata. Ketiga Sintaksis yaitu Mengurutkan kata dalam menentukan arti yang tersusun dari Subjek, Predikat, Objek dan Keterangan. Keempat Semantik yaitu Mengetahui artiarti atau makna yang terkandung tiap kata dengan kata lain. Dan Kelima Pragmatik yaitu Menggunakan bahasa yang sopan dalam situasi-situasi yang tepat. Dan hasil capaian dari kelima aspek perkembangan bahasa anak usia dasar tersebut bahwa hampir keseluruhan indikator dicapai dengan sangat baik. Hanya indikator perkembangan pragmatik yang masih cukup atau mulai berkembang. Adapun untuk hasil keseluruhan perkembangan pengetahuan bahasa anak usia dasar di MI Ma'arif Sambego dapat dikatakan sangat baik atau sudah tercapai.

\section{REFERENSI}

Abdul ,Chaer (2009). Psikolinguistik: Kajian Teoretik, Jakarta: PT Rineka Cipta

Ahmad, Susanto.(2012). Perkembangan Anak Usia Dini: Pengantar Dalam Berbagai Aspeknya. Jakarta: Kencana

${ }^{31}$ Laode, Abdul Wahab "Pemerolehan Pragmatik Pada Anak Usia 3 Tahun (Studi Pada Asysyifa Ibra Him Warga Kendari Barat)”, (dalam Jurnal Al-Ta'dib Vol. 6 No. 2 Juli Desember. 2013).

${ }^{32}$ Beverly Otto, Perkembangan Bahasa..., hlm.354. 
Vol. 2 No 22019

Asy'ari, Hasyim. "Keistimewaan Bahasa Arab Sebagai Bahasa Al-Qur'an." Nidhomul Haq: Jurnal Manajemen Pendidikan Islam 1, no. 1 (2016): $21-$ 28. https://doi.org/10.31538/ndh.v1i1.5.

Beverly, Otto. (2015). Perkembangan Bahasa Pada Anak Usia Dini. Jakarta: Kencana

Dardjowidjojo .2005. Psikolinguistik; Pengantar Pemahaman Bahasa Manusia. Jakarta. Yayasan Obor Indonesia.

Dyah, Rohma Wati. "Sendi Sintaksis Dalam Pemerolehan Bahasa Pertama (Sebuah Studi Kasus)".

Ellis Gail dan Brewstar jean. 1989. The Storutelling Handbook for Primary Thachers England Penguin English.

Harimurti, Kridalaksana. (2008). Kamus Linguistik. Jakarta: PT. Gramedia Pustaka Utama

Ida, Hamidah.(2018). "Pemerolehan Bahasa Pada Anak Usia 3,5 Tahun Berdasarkan Aspek Fonolog”. Dalam Jurnal Ilmiah SPS Pendidikan Bahasa Indonesia, Vol 1, No. 1, Agustus

Johw ,W Santrock. (2007). Perkembangan Anak. Jakarta: Erlangga

Kridalaksana, Harimurti. 1993. Kamus Linguistik, Jakarta: Gramedia Pustaka Utama.

Kuhl., P.K \& Meltzoff, A. N. (1997). Evolution, Nativism and Learning in the Development of Language and Speech. NY: Oxford University Press

Laode, Abdul Wahab .(2013). "Pemerolehan Pragmatik Pada Anak Usia 3 Tahun (Studi Pada Asysyifa Ibra Him Warga Kendari Barat)".dalam Jurnal AlTa'dib Vol. 6 No. 2 Juli - Desember

Lenny, Nuraeni. (2015). "Pemerolehan Morfologi (Verba) Pada Anak Usia 3, 4 Dan 5 Tabun (Suatu Kajian Neuro Psikolinguistik)" .dalam Jurnal Tunas Siliwangi Vol.1 | No.1 | Oktober 
Mansur. (2014). Pendidikan Anak Usia Dini dalam Islam.Yogyakarta: Pustaka Pelajar

Mushaitir. (2016). "Pemerolehan Sintaksis (B1) Bahasa Sasak Pada Anak Usia 4-6 Tabun”, dalam Jurnal Pendidikan Bahasa dan Sastra, Volume 16, Nomor 1, April

Nababan, P.W.J. (1987). Ilmu Pragmatik (Teori dan Penerapannya). Jakarta: Depdiknas.

Nurjamiaty. (2015). "Pemerolehan Babasa Anak Usia Tiga Tabun Berdasarkan Tontonan Kesukaannya Ditinjau Dari Kontruksi Semantik". dalam Jurnal Edukasi Kultura Vol.2 No.2 September

Rowin, Inchinia Angger. "Verbalisme Bahasa Arab Dalam Kehidupan Beragama Masyarakat Muslim.” Nað̧runa: Jurnal Pendidikan Islam 1, no. 1 (16 Agustus 2018): 20-36. https://doi.org/10.31538/nzh.v1i1.40.

Prima, Gusti Yanti. (2016). Pemerolehan Bahasa Anak: Kajian Aspek Fonologi Pada Anak. dalam Jurnal Ilmiah VISI PPTK PAUDNI - Vol. 11, No. 2, Desember

Purwo, Bambang Kaswanti.(1997). Pelba 10. Jakarta: Lembaga Bahasa Unika Atma Jaya.

Samsunuwiyati Mar'at. (2005) . Psikolinguistik: Suatu Pengantar:Bandung: PT RefikaAditama

Sugiyono.2014. Metode Penelitian Kuantitatif Kualitatif dan R\&D. Bandung: Alfabeta.

Suharshimi, Arikunto. (2007). Prosedur Penelitian: Suatu Pendekatan Praktik. Jakarta: Rineka Cipta.

Yusuf, Syamsu. (2011). Psikologi Perkembangan Anak dan Remaja, Bandung: PT Remaja Rosdakarya 